\title{
Educational Leadership Effectiveness. Is it a Matter of a Leader's Characteristics, Behaviors, or Leadership Style?
}

\author{
Andreas Dimopoulos ${ }^{1}$ \\ ${ }^{1}$ Department of Economics, Faculty of Social, Political, and Economics Sciences. University of Thrace, Greece \\ Correspondence: Andreas Dimopoulos, Fragma Thermis, Thessaloniki 57001, Greece. Tel: 30-6936-346617. E- \\ mail: job1j@yahoo.gr, info@andreasdimopoulos.gr
}

Received: January 9, 2020; Accepted: February 17, 2020; Published: February 22, 2020

JEL Classification Codes: J48, I25, JA23, I20, I28.

\begin{abstract}
Leadership in education has been examined in depth until nowadays regarding among others the most common models of leadership, the personal characteristics and profile of charismatic leaders, the principal leadership style and behavior. Notwithstanding, to the best of our knowledge so far, there is space for additional examination as far as for educational leadership effectiveness regarding these factors. This study aims to investigate the outcomes of educational leadership considering the most important components of leadership which are the leader characteristics', behaviors' and the most common exercised styles. Furthermore, a purpose of this study is to explore interconnections and correlations among leader characteristics', behaviors, leadership styles and effectiveness. According to literature review, there is no clear answer in the question of which one component among leadership styles', personal characteristics' and behaviors' is more significant and contribute more to leadership effectiveness. Research has shown that all these elements are fundamental and are considered all important for educational effectiveness. It is also argued that there is a strong interconnection between them as individual parts in an integrated system, which each one separately has its relative influence in educational leadership effectiveness. Also, there is a broad tendency for agreement according to which educational leadership effectiveness depends on many other factors apart from characteristics', styles and behaviors', such as timing, special conditions, legislation, personnel qualifications, expected outcomes' importance, facilities and many others. Apart from these independent factors it is worth to mention that different leadership styles have different positive or negative outcomes to different stake holders. Therefore, it is hard to isolate and to define which of those components are more significant for leadership effectiveness.
\end{abstract}

Keywords: education, leadership, management, efficiency, effectiveness, styles, characteristics

\section{Introduction}

\subsection{Statement of the Problem and Purpose of the Study}

Numerous endeavors until now have attempted to assess and survey leadership outcomes and educational leadership effectiveness across the world in, primary and mainly in secondary and higher education tiers. Many studies have been made in leadership exploring leaders' characteristics, behaviors and styles but exploring the contribution of each one of these components to leadership effectiveness still remains significant. The primary issue in this research is to explore the effectiveness of leadership regarding these basic components and correlations among them. A further aim of this study is to accompany the research with an appropriate assessment questionnaire for educational leadership effectiveness using metrics and relative criteria to leaders' actions and behaviors.

\subsection{Interpretation of Educational Leadership}

The issue of leadership and its results has occupied mankind over time from antiquity to today, and been considered by researchers, scholastics, scientists, business and associations executives, private and public sectors, politicians and governments, organised societies and informal organisations, military structures, educational organizations. The interpretation and analysis of the concept of leadership has been made at times either on the premise of the qualities of the leader personality, or on the basis of the behavior of the leaders, either on the basis of the result obtained and the style of command, or with 'hybrid' models that they combine the above theories. Also, schools so as to check improvement process frequently look at the different initiative factors that assume a considerable job 
in school effectiveness (Bruggencate, Luyten, Scheerens, \& Sleegers, 2012). This research aim to create reflection, make inferences on educational leadership, associating the effectiveness of leadership with the characteristics of the leaders, the leadership models, their behaviors and correlations among them.

\subsection{Educational Leadership Effectiveness}

Ordinarily there are an assortment of inquiries concerning leadership, administration, for instance if this is effective, or what are the elements that characterize it as effective, or whether the characteristics of the leader or the leadership style are those that determine its effectiveness, or more simply when a leader is able or not, adequate or inadequate. This research endeavors to depict and investigate the effectiveness of educational leadership regarding the educational leaders, personal characteristics, leadership styles' and behaviors

\section{Method}

\subsection{Research Design}

In this study an extensive relative literature review in educational leadership has been directed, so as to investigate inside and out the most important components of educational leadership. More specifically subject of this research is whether educational leadership effectiveness depends on the posses off leader personal characteristics, the applied specific behaviors, or the appropriate styles and witch one of these elements is considered to contribute more to leadership effectiveness. This research is based exclusively in literature review with a purpose to set the necessary research questions and to shape the framework about the most significant components of educational leadership which according to other studies contribute more to effectiveness. In a subsequent survey, a relative questionnaire will be presented regarding the level of significance in educational effectiveness of each one of the most important components of leadership and the correlation among them with effectiveness. More specifically with the questionnaire will try to assess the relative importance of leaders' behaviors and evaluate which of these particular components considered as more important and have greater impact in educational leadership effectiveness, regarding teachers' approach as participants stake holders in a real sample.

\subsection{Research Questions}

The general research hypothesis that this study try to answer is whether the effectiveness of the educational leadership is a result of some particular characteristics that distinguish the successful leaders of education, or whether the effectiveness of leadership is a product of specific leadership behaviors or of appropriate leadership styles. There are three basic research questions on which we will attempt to answer, by quoting the conclusions of other relevant research on the basis of the literature

Research question 1: If the results of the educational leadership which is implemented are influenced by the personal characteristics of the leaders and what are these specific characteristics.

Research question 2: If the results of the educational leadership are influenced by the leadership exercised style and behaviors and which are the main styles.

Research question 3: Which is the most significant component among characteristics', styles and behaviors of leadership effectiveness?

\subsection{Educational Leadership is a Broad Interest}

The study of educational leadership is increasingly interesting. This is because, on the one hand, the results of the educational function are methodically explored; on the other hand the leaders' impact on results is sought according to Leithwood and Riehl (2003).

Also another reason for the strongly intrigued within the field of education is that it has ended up requesting, there are always changes, coming about in modern challenges for leaders. Leadership in school organisations has gotten to be a need in educational policy worldwide. It is considered that plays a fundamental role in improving school results and progress, by impacting the inspirations and capacities of instructors, as well as the school climate and environment. Viable school administration is basic to move forward the effectiveness and value of tutoring (OECD, 2008). School pioneer is considered as one of the foremost influential components in the advancement of the quality and identity of a school factors (Cohen, McCabe, Michelli, \& Pickeral, 2009).

A great part of the past research exhibits that principal's leadership style and aptitudes, influence a variety of teacher qualities, from work satisfaction and effectiveness, to levels of commitment and scholarly accentuation (Bird et al., 2009). It has high effect on the improvement of the consequences of the school, having the capacity to impact the inspiration and execution of educators by making the suitable atmosphere and workplace environment (Pont, Nusche \& Moorman, 2008). Furthermore, research has proven that principal leadership can have indirect but a significant, impact on student results (Hallinger \& Heck, 1996; Marzano, Waters, \& McNulty, 2005; 
Robinson, Lloyd, \& Rows, 2008). The growing expectations of individuals and organisations, within or outside the education as well as from schools are viewed as the most significant component which builds the significance of leadership in education (Hoy and Miskel, 2010). What's more, the various groups of individuals that are 'included' or are beneficiaries of any type of educational leadership for example educators, students, parents, depend to an enormous degree on the choices of the educational leader as should be obvious from the posting of the relevant literature.

\subsection{Educational Leadership. Definitions}

Over time many researchers globally tried to deliver the concept of educational leadership, resulting in many different definitions depending on the way everyone approaches it. It is essential that some of them should be mentioned in this respect. Through the listing of relevant definitions for the educational leadership and the analysis of these, we can understand several of those particular components that are at the same time the effectiveness criteria of the educational leadership. Therefore, realizing as good as possible the definition of educational leadership and the individual important elements that compose it, such as actions, behaviors' and styles, we can understand better and distinguish these elements that judge a leadership as effective.

Educational leadership is the ability to steer the flow of the organization and staff in the operation of the school contributing to the achievement of educational goals, and the role of school leaders is to recognize and synchronize the staff to meet the needs of pupils with the ultimate goal of maximizing student successes (Adelman \& Taylor, 2006). Educational leadership can imply as an influence process based on net values and beliefs that lead to a school's vision. This vision is articulated by the school leader who seeks the commitment of staff and stakeholders to an ideal school's best future, pupils and other interested parties (Bush, 2007). According to Spillane, Halverson and Diamond, (2001) as educational leadership is characterized the recognizable proof, securing, distribution, coordination and utilize of social components and cultural resources, which are considered essential for the establishment of competent teaching and learning conditions. Another approach to the concept of educational leadership indicates that teacher's leadership is defined as the process in which teachers are leaders not only within the classroom, but also 'outside' of it, they identify their task and contribute to a community where teachers become leaders and pupils, encourage their colleagues to adopt new educational practices, and accept responsibility for achieving the goals as they are formed through the Leadership practices that adopt (Katzenmeyer and Moller, 2001). Through their involvement in this field, educational leaders must also focus their attention on improving teaching practices, judging their practices in collaboration with colleagues, be knowledgeable about teaching programs and to be able to participate in their design, to choose the material to be used in their teaching, to participate actively in decision making, to involve other educators in the fields of reflection and research, and to evaluate their performance (Harris and Mujis 2005; Barth, 2011). According to OECD a study off Pont, Nusche and Moorman, (2008) main responsibilities of school leaders be clearly defined and delimited to improve teaching and learning in four significant domains of duty as key for school authority to improve student results: supporting, assessing and developing teacher quality, target-setting, assessment and responsibility, strategic financial and human resource management, working together with other schools. Numerous other studies have contributed to the addresses of what constitutes effective educational leadership (Leithwood et. al., 2004; Heck \& Hallinger, 2009; Murphy and Vriesenga, 2007; Darling-Hammond \& Richardson, 2009). The main elements regarding effectiveness which identified across them, suggest that an effective leader sets a clear strategic direction for both instructional and organizational development as well, creates the parameters for improving student performance and supports and develops people. Leadership at the school level is required to perform multi-dimensional roles and a leader must be equipped with such capacities and aptitudes so as to realize the set targets (Lopez \& Ensari, 2014)

If one could summarize these perspectives and reconcile key points, it would say that educational leadership includes concepts relating to the knowledge, skills, abilities, characteristics, attitudes and behaviors of educational leader, concurrently with results in specific directions. In this perspective, educational leadership is a broad framework of actions, behaviors, skills, and objectives. In this framework leadership goes beyond of the narrow limit of management and objectives such as the application of the rules of law, the allocation and management of resources, the organization and coordination, which constitutes the administrative side of educational leadership. Rather, educational leadership entails also competences such as stimulation, empowerment, influence, inspiration, development of personnel, which respectively shape leadership styles and these consequently affect the formation of school climate, working conditions, shaping behaviors', culture, vision, that are the other essential side of leadership. 


\subsection{Characteristics and Distinct Traits of Effective Leadership}

There are distinct traits for determining effective leadership. These traits as we will see later on are mainly related to two components of the leader. The first component relates to the characteristics associated with leader's personality and the second component relates to leader's behavior and leadership style witch deploys. The perpetual question that concerns those who are puzzled about the issues of work and more generally about the issues of management in companies and organisations relates to which of the characteristics or behaviors' make someone a leader in his place of work. Furthermore, while some exploration has moved from conventional attribute or character based speculations, towards to a situational theory which directs that the condition wherein administration is executed is dictated by the abilities and qualities of the leader (Avolio, Walumbwa, \& Weber, 2009), every single modern hypothesis can grouped under one of the accompanying three points of view: leadership as a procedure or relationship, leadership as a mix of characteristics or character attributes, or leadership as specific behaviors or, as they are more in common referred to, leadership abilities. At this point it is therefore appropriate to refer to some of these characteristics which according to the literature are referred to as important or as common traits of successful leaders. Stogdill, (1974) as cited by Gosling and Dennison (2003) regarding the distinctive attributes of people who have been considered as leaders showed the following essentials components in making someone leader; intelligence and scholarship, physical traits, personality, social status and experience and task-work orientation. He also identified the main leadership traits as follows: adaptable to circumstances, alert to social conditions, ambitious and target achievement-oriented, cinfident, cooperative, decisive, reliable, dominant with desire to influence others, energetic persistent, self-confident, tolerant of stress and ready to accept accountability. The skills accordingly identified as follows: clever (intelligent) conceptually gifted, creative, diplomatic and tactful, fluent in speaking, knowledgeable about group task, organized (administrative ability) persuasive and socially skilled.

\subsection{The Theory of Individual Characteristics and Effectiveness}

A significant relationship was found between principals' leadership skills and school effectiveness (Akinola Oluwatoyin Bolanle, 2013). Skill, according a theory is used to indicate ability developed in the course of training and experience. The common factor for the distinctive types of abilities is that the leader must combine the request of a specific duty to the right skill which is viewed as vital for the effective achievement of the duty (Gregory, 2001). Peterson and Van Fleet (2004) suggested ten categories of skills essential for effectiveness. They were technical, analytic, decision-making, human, communication, interpersonal, conceptual, diagnostic, flexible and administrative skills. Another study recognised four general categories: cognitive, interpersonal, business and strategic skills (Mumford, Campion and Morgeson, 2007). In an effort to approach the characteristics of the effective leadership Hoy and Miskel, (2008) classify these characteristics into three categories: a) in the category of personality (self-confidence, emotional maturity), b) in category related to job stimulation (task, expectation) and c) in the category of leadership skills (administrative, interpersonal). Richter, Lewis and Hagar (2012), found transformational, administrative and behavior management skills to be essential components that principal need for accomplishments in an effective school.

The approach based on the personal characteristics of the leader was based on the belief that leadership is an inherent gift that only important people possess and which gives them characteristics and qualities that make them different of the others (Northouse, 1997). Studying the personality of important leaders from the field of politics, religion and the army, scholars have resulted in certain characteristics of the leader, of which the following are mentioned: intelligence, confidence, determination, credibility, sociability. It has emerged that the style of leadership and the characteristics of the leader influence a range of attributes of the professors from their job satisfaction and effectiveness, up to the levels of their active participation and the academic emphasis they give (Bird et al., 2009), as well as their engagement in organisation and their work satisfaction (Aydin et al., 2013). Furthermore, despite the fact that it has been seen that leader aptitudes might not directly affect students' results, his/her abilities can affect the important relationship with teachers (Cotton, 2003).

But the characteristics based approach has many weaknesses. One of them is the plethora of features that are periodically presented as indicative of the leadership profile and the inability of scholars to agree on some of them. Another weakness is the devaluation of other factors that coexist in the exercise of leadership, such as the different circumstances, situations or people concerned. Also, the leadership approach based on the characteristics of the leader receives criticism as to its credibility, because it has not succeeded in linking the characteristics and qualities of the leader with specific results of the administrative process, such as for example can be to increase the productivity and satisfaction of employees from the work they do (Northouse, 1997). 
Thus, an evaluation of leader effectiveness based solely in his/her certain personal characteristics could not be an effective, objectively and broader accepted model. However, aspects of leader's personal characteristics' should be a part of a holistic leadership effectiveness evaluation process because these characteristics have significant direct or indirect affects in many outcomes.

\subsection{The Theories of Behavior and Effectiveness}

In studies on the theory of the behavior of the leaders, characteristically was one by researchers at the University of Michigan Lussier \& Achue, (2010) where emphasis was placed on the leader's behavior and not on his/her features (atomic theory Characteristics) concluding that the combination of both dimensions leads to a more effective leadership model. Respectively in the research of Leithwood et al., (2004) for the effect of the effectiveness of school directors on learning outcomes was found that the actions that a director had to make to be effective are the creation and maintain a competitive school, strengthen other parties, empower teachers to make important decisions, provide educational orientation, develop and implement school improvement plans. Respectively, McGregor, (2000) investigating the reasons that stimulate teamwork among educators, observes that group leaders maintain and reinforce a culture of cooperation. These cultures share values and aim to move forward instruction and learning so that to meet the requirements of pupils and to empowering teachers' professional development.

The wrong leadership implementation, in relation to the above objectives which is to strengthen the group, is likely to weaken the team collective effort of the members of a group (Robbins and Finley, 2000) and the failure to maintain its effectiveness, as its members will not be able to coordinate and act harmoniously. The proper implementation of leadership strengthens teachers in the effort to change mentality and to adopt a collaborative teaching model, aiming at the development of effective groups in school organizations (Harris, 2009). Furthermore, leadership is a key component in the development and sustainment of school climate (Bass \& Riggio, 2006). Respectively, according to Vos et al., (2012), an unhealthy school climate can lead to ineffectiveness. Owens (2004), and Vos, van der Westhuizen, Mentz, and Ellis (2012) found that the behaviour of principals has particular influence on school climate, as the certain strategies used to manage the campus, influence the experience of the teachers and the total work climate. Also, the behavior of the principal, especially when it is supportive, collegial, and not overly restrictive, can have a positive impact on student achievement through the impact this behavior has on school climate and thus his or her teachers (Tschannen-Moran \& Tschannen-Moran, 2011). Additionally, Bird et al., (2009) discovered that teachers' engagement-commitment levels were strongly related to their level of trust in the school, their colleagues and their principal. Given the fact that the overall campus climate contains a critical impact on the staff job satisfaction, it is of particular importance to evaluate organizational health to sustain positive work performance (Vos et al., 2012).

\subsection{Leadership is a Complicated Function}

At this point, through the quotation of previous reports, it is understood that the exercise of leadership is based on the characteristics of the leaders, which consequently interact with their behavior and the way leadership is applied. Therefore, leader's behavior is a critical element but this behavior is correlating with leader's personal characteristics and traits. It seems that the behavior is that one which distinguishes leadership and is of prominent importance combined with the characteristics of the leader. Besides according to Ulrich et al., (1999) the phenomenon of leadership has been interconnected with the necessity of successfully achieving results and defining as effective leadership: leading behavior $\mathrm{x}$ results.

Of course at this point raises the question, if the specific actions and attitudes of the leaders are influenced, or come to a small or to a large extent from the characteristics of their personalities, or from skills and abilities that leaders have, and consequently how these as characteristics cause, shape, reinforce or weaken such behaviors respectively. This complex assumption result in the question as to whether the effectiveness of leadership, is ultimately a result of characteristics or behaviors and vice versa, which still becomes more complicated in its response. According to another research there are three major components of that clarify the discussion discourse: (a) an attribute of an office or position, (b) a characteristic of a individual, and (c) a category of actual behavior leadership (Katz and Kahn, 1978). In other words, there is a logical interaction between the leader's characteristics and the way in which the leadership is exercised, which is manifested by specific behaviors' and results. Hence, the leadership in educational institutes is both simple and complex process (Leithwood et al. 2004). Another research advocates stating that the leadership style which is exercised by school leaders is complex and plays a necessary role in creating the culture in a school (Fullan, 2001). Moreover, as Valentine and Prater (2011) stated, the principal's role has become increasingly complex as the nature of society, political expectations, and schools as organizations have changed. 
Therefore, an evaluation of leader effectiveness based solely in his attitudes, behaviors' could not be an effective, objectively, crystal clear and broader accepted model. However, aspects of leader's behaviour should be a part of a holistic leadership evaluation process, because these skills and accordingly relevant behaviours' have significant direct or indirect affects in many outcomes through leadership styles that deployed.

\section{The Theories of Leadership Models-Styles' and Their Effectiveness}

In the study on educational leadership, various models have emerged and developed in terms of the elements that distinguish these models and their effectiveness. For instant Vroom (2000) believes that the style which a leader deploy for making choices is considered as a significant component of effective leadership, which is recognized as a technique utilized for improvement of the decision-making process. The leadership style has also been found to have an influence on teachers' motivational level (Eval and Roth, 2011; Waheed, Hussin, \& Daud, 2018) and job satisfaction, making a learning environment in school, to manage employee resources and to create a change process in school (Waheed, Hussin, \& Daud, 2018). More specific, teachers' work satisfaction and engagement to their work are in a direct relation with the leadership style employed by their principal (Hauserman \& Stick, 2013). Moreover, overwhelming evidence reveals how school educational leadership style influence instructors' behaviors and their beliefs towards them. It has also been found a positive relationship among the leadership style and effectiveness, but found no relationship with school performance (Ibrahim, \& Al-Teneiji, 2013).

Agreeing to existing discoveries considering the leadership impact on staff, there are numerous definitions of leadership and relative behaviors', which do have an influence on their workers. Leaders who embrace both transformational and transactional leadership practices are the foremost powerful leaders (Bass, 1985). Also, has been found that teaching staff have had a high level of positive opinions regarding transformational and transactional leadership qualities of school leaders (Avci, 2015). Moreover, leaders must also possesses transactional leadership skills before deploys the style of transformational leadership and it proposed that basic components of both transactional and transformational leadership were present in leaders who were effective (Bass, 1997). Transactional, transformational, inspirational, and instructional leadership styles are available, appear in some way in most leaders, but seldom are they found to be exclusive. Bass and Avolio (1994) accepted that these styles of transactional and transformational leadership are not dichotomous. They hypothesized that many of the leader qualities of transactional leadership must be available before transformational attributes can develop.

Therefore, an indicative report of the most well known different leadership styles and their complimented behavior is advisable firstly to consider the correlation with the effectiveness of these models and secondly to highlight that different models' of educational leadership have different results in different directions.

\subsection{Transactional Leadership}

Transactional leaders identify primarily tasks of the followers; build up the structure, emphasis on planned and arranged work. Followers are compensated or punished to accomplish organizational targets (Hoy \& Miskel, 2010). Transactional leadership involves helping organizations through managing to achieve their current objectives efficiently, such as by linking job performance to valued rewards and ensuring that employees have the resources needed to get the job done (Avollio, \& Bass, 1988). This leadership style is advantageous in managing the organization, and in directing the system within the framework of mission, vision and values of the organisation (Bass, 1997). However, this style has weakness in rearranging the organization and the institutional structure quick in terms of innovation, entrepreneurship, reform and needs which are compulsory in today's competitive environment, and in showing results beyond expectations by collaborating with the staff and acting with a team, in a cooperative spirit (Yukl, 1989; MacKenzie et al., 2001). But transactional leadership practices also are less likely to be positively correlated with teachers' self-efficacy (Hipp, 1996; Nir \& Krano, 2006; Walker \& Slear, 2011). A study conducted by Walker \& Slear (2011) concluded that contingent reward particularly, had negatively correlation with teachers' self-efficacy (pp. 52). But on the other hand, self-efficacy of teachers is a crucial factor of their aims and behavior. The significance of leadership style in determining the self-efficacy of teachers is not only pivotal to organizational climate and management; it is also crucial for teachers' results and their performance. Self-efficacy is considered a context-specific and multidimensional construct (Zimmerman \& Clearly, 2006, pp.47)

\subsection{Transformational Leadership}

Leithwood (1994) contributed to the conceptualization of transformational leadership in educational situations. On the premis of seven quantitative studies he has take out after conclusion (Leithwood, 1994, p. 506): "Transformational leadership practices, considered as a composite construct, had significant direct and indirect effect on progress with school-restructuring initiatives and teacher-perceived student outcomes"'. Studying the effects of transformational leadership has identified as many as twenty studies which provided evidence of the relationship between leadership and the teachers' outcomes (Leithwood et al., 1999). Many studies have undergone 
examining the correlation among transformational leadership and various variables and showed that this style has positive impact on: satisfaction (Griffith, 2004; Leithwood \& Jantzi, 2008; Bolger, 2001), motivation (Griffith, 2004; Kruger, et al., 2007), commitment (Geijsel, et al., 2003; Yu, et al., 2002; Leithwood \& Jantzi, 2002;Hauserman and Stick (2013) professional growth (Kruger, et al., 2007), school learning culture (Barnett, McCorminck \& Conners, 2001; Kruger, et al., 2007; Silins, Mulford \& Zarins, 2002) school culture (Barnett \& McCormick, 2004), school climate (Blatt, 2002), student achievement (Griffith, 2004; Leithwood \& Jantzi, 2008; Marzano, Waters \& McNulty, 2005; Chin, 2007; Politis, 2001; Finnigan and Stewart, 2009).

Also, the influence of transformational school leadership on pupil engagement is significantly positive (Leithwood, et.al 2008). According, to Bass, (1985) the leadership of large historical forms over time was transformative and not transactional. The Leadership model (Multi-Factor Leadership Questionnaire) developed by him and his associates has shown that employees who give high marks to their leaders in transformational components, also rate them as extremely effective, unlike those highly rated in trading components and considered less effective. As stated by Bass (1985), elements which describe the conduct of transformational leaders are: individual consideration, intellectual stimulation, inspirational motivation, and idealized influence. There is evidence based on research which demonstrates a positive relationship between transformational leadership and school environment, teachers' job satisfaction, organizational commitment, development of an innovative climate in schools and students' achievements (Nguni, Sleegers \& Denessen, 2006; Sun \& Leithwood, 2012).

\subsection{Pros, Cons and Differences Between Transformational and Transactional Leadership Style}

Empirical research by Masi and Cooke (2000) looked at the effect of Transformational leadership and Transactional leadership on adherent motivation, empowerment, and commitment to quality. They found that transformational leadership tends to empower and motivate adherents, while transactional leadership tends to suppress follower commitment to both quality and productivity. Burns' (1978) about transformational leadership theory has stated that this is different in basic elements from other theories of leadership due to its orientation to long-term vision, by its concentration on personal followers' development and thus the transformation of the followers into leaders and ethical agents. In particular, the mutual interaction between transformational leaders and followers the level of morale and motivation of both is raised. The transformational leadership style has been too criticized since its inclination to consider the leader as a hero, missing some significant leadership factors, having questionable concepts and focusing on certain transactional practices (Leithwood, \& Sun, 2012; Yukl, 1999). Moreover, Hauserman and Stick (2013) found that transactional leadership has limited capability for success, while transformational leadership is considered to lead to advantageous long-term performance.

\subsection{Distributed Leadership-Sharing Leadership}

The school leadership that leads to effectiveness is the distributed leadership as effective school leaders take care of the development of other leaders in the school area who will assume responsibilities in the present, and they will continue their work in the future (Hargreaves \& Fink, 2008). In addition, Spillane, (2005) argues that shared leadership is not the "magic" recipe for all school problems, but a very useful tool for dealing with these and finding solutions. The role also of the consultant of education in shared leadership can be significant by reinforcing its effects (McCarty et al., 2014). Effective schools are considered those which provide opportunities for professional development, and are made up of good leaders who encourage teachers to actively engage in changes in their schools (Riley and MacBeath, 1998). Therefore, the role of the teacher must be redefined so that teachers should be placed among the leaders of the school community and contribute to the implementation of effective leadership practices and improvement of the learning process. On the other hand, regarding the importance of distributive leadership for significant and long-term school reform, as Barnett et al. (2001) have found a visionary head educator can really divert and distract teachers from focusing on teaching and learning, not to mention having ownership of the vision!

\subsection{Contingent Theory and Leadership Effectiveness}

According to the contingent theory, the behavior of the leader is determined by the interaction of both his personality and the situations prevailing in the wider environment. Fiedler's contingent theory argues that the effectiveness of leadership is influenced by the circumstances in which the leader operates and briefly advocates the view that "we can talk about a leader who is effective in a particular situation is not effective in another" (Fiedler, 1976). His research showed that when there are situations of high or low control, it is preferable for the leader to be oriented towards a project. But in the case where we refer to an intermediate situation, it is preferable for the leader to be oriented towards human relations. Therefore, there is no unique way of exercising leadership, suitable for all situations. According to the contingency theory, no single leadership style is appropriate in all situations. Success depends upon a number of factors, including leadership style, qualities of followers and 
situational characteristics (Charry, 2012). In recent years it has been argued that single-dimensional leadership models are no longer considered as key factors for school improvement (MacBeath, 2011). What is considered necessary is the combination of many leadership theories, which achieve the most positive results (Riley and MacBeath, 1998). However, there is an agreement that the ideal style of leadership depends on each situation that is to be dealt with and varies, i.e. case (Bass, 1985).

With regard to which leadership model is most effective, we could say that there is no clear and absolutely correct answer. This means, that the effectiveness of leadership standards in workplaces depends on many parameters such as, special occasions, circumstances, possibilities, opportunities or threats of the environment, and the leader should under the changes of the circumstances and the available data to adapt the leadership model accordingly, by evaluating data, and prioritizing the goals that wants to achieve in a given time period. In conclusion, we would say that no leadership model is a panacea, as most suitable and effective for all occasions and for all working or operational areas. The appropriate combination of the required personal characteristics of the educational leader, with the circumstances and data of the given time period, the characteristics of the group, and the objectives pursued, is the one that enhances the efficiency. Summarizing another survey reinforce this, stating that the success of educational leadership is assured when the implementation of leadership styles, fundamental principles and methods are properly and fully implemented in the management of the school and that the leadership styles depend on their application by parameters such as the size of the organism, the degree of interaction, communication between members, the personalities of members, the commitment to the success of a common goal, the level of decision-making (Amanchukwu et al., 2015). After all, according to (Bass \& Bass, 2008) good leadership develops through a never-ending process of personal study, education, training and concentration of related experience.

The leadership models exhibit significant conceptual overlaps, are not easy to clarify fully and although there are distinct features between them, however, it is not possible to have an absolute ranking of a leader exclusively in one, or other form. It is concluded that the various models of educational leadership produce different outcomes to different recipients and their effectiveness depends generally on the circumstances and the specific conditions under which educational leadership is exercised.

While comparing instructional, transformational, distributed and sustainable leadership styles, it is argued that each of these leadership styles have their own merits and demerits; however, a flexible leadership style having elements of each, would be most appropriated and applicable (Mulford, 2008). Similarly, Hallinger (2003) argued that the effectiveness of transformational and instructional leadership depends on school factors; however, if both of them were integrated, the contribution would be better as an outcome.Bass (1998) believes that every leader displays practices of both styles to some extent. Although, transformational and transactional leadership are at opposite ends of the leadership continuum the two can be complementary (Leithwood \& Jantzi, 2000)

Therefore the evaluation of the effectiveness of the educational leadership on the sole criterion of the applied leadership style itself cannot be a credible, objective and generally accepted method. However, leadership style should be a considerable part of a holistic leadership evaluation process, due to the influence that exert to many stake holders and to direct or indirect effects that has in many outcomes'.

\subsection{Evaluation of Educational Leadership Effectiveness could be Made in Various Criteria}

The implementation of educational leadership style in an educational organization certainly has multiple effects to many recipients' and therefore its effectiveness must be explored in the light of the positive or negative influence to all of them. A large number of the globally acknowledged attributes of school efficiency such as shared vision, mission and achievement of goals, are the product of an effective school leadership (Catano \& Stronge, 2006). The role of leadership in education system is of critical importance for both the educational, school and the entire education system, and its effectiveness has been explored in relation to 'many' different variables, such as the school climate (Clifford et al., 2012; Allen, Grigsby, Peters, 2015) creating a sense of community in school (Beck \& Foster, 1999) and especially in relation to student outcomes, for example pupils' achievement (Henderson \& Mapp, 2002; Leithwood, 2002; Leithwood et al., 2004; OECD, 2013; Allen, Grigsby, Peters, 2015; Portin, et al., 2009) andteachers' expectations from the school leader (Thompson, 2017). As they say (Everard \& Morris, 1999) an effective director inspires, motivate students and teachers and promotes the offer of equal learning opportunities. It has a stable administrative path, credibility-reliability, creates a climate of mutual respect, sets targets and conducts them, has flexibility, and over take initiatives. It shows confidence, creates positive, pleasant and creative climate, rationally manages the economics of the school, has the ability to guide students and enforce discipline, has the ability to influence the members of the school community and to lead them to positive results, collect information, cooperate with students, parents, academic, teaching staff and other bodies. 
Therefore, an assessment of leader effectiveness based in objective, qualitative or quantitative criteria of achievement towards targets which have been set from major stake holders, could be more reliable, objectively, accountable, and wide accepted model. But such a model of evaluation should incorporate the leader's characteristics, behaviors and styles in order to be fulfilled.

\subsection{Educational Leadership Effectiveness and Considerations}

So far, it is understood that the effectiveness of educational leadership is a concept that can be identified with sufficient, objectively to a large extent, multiple criteria and parameters both at administrative tasks and in teaching outcomes such as development of the human capital of educational units, the level of their work satisfaction, the formation of climate and attitudes, students' performance and achievements.

But to achieve a well documented result, to a larger possible extent, is necessary to take into account as much as possible, objective and measurable criteria considering the characteristics' of the leader, his or her behaviors' and the leadership style. Accordingly, efficiency is the result of achieving the objectives that are come with by the appropriate behaviors', which in turn are influenced and shaped by the particular characteristics of school leaders and their leadership style which is exercised.

In other words, when we think about the concept of effective educational leadership assessment, we should consider this as a dynamic, complex function, based on foundations, such as the attributes of the personality of the leader and the members of the team, culture and maturity of the group, with a set of explicit targets and the objectives pursued respectively, in a specific time period, with a constructive, impartially and defined process.

\subsection{Suggestion for an Educational Leadership Evaluation Model Based on Teachers Approach}

Assessing the effectiveness of educational leadership is a process that involves many different stakeholders. In particular when the evaluators' of educational leadership effectiveness are the teachers, then the outcomes of leadership that have a significant impact on them could be assessed towards their relative criteria regarding the leader. These could be for example, the applied management and leadership style, the behavior, possessing of certain important characteristics of the leader. These are basic leadership components that produce positive or negative outcomes to them and to school organization, such as for example the school climate, the learning and teaching environment, teamwork spirit, cooperation among teachers and administrative staff, shape of good or bad working conditions, relations among students, teachers, parents and community, job satisfaction, staff engagement, vision and eventually, overall school outcomes. Thus, leader's characteristics and certain attributes such as for example integrity, influence, persuasiveness, empathy, emotional intelligence, encourage, commitment, empowerment, fairness, support, plays a pivotal role to exercised leadership style and to effectiveness.

\section{Discussion}

Educational leadership effectiveness is an issue that increasingly concerns the community of educators, researchers, parents, students, education in general, and a large number of studies have undertaken on the issue of its effect on the various addressees of this (McCarty et al., 2014; Aydin et al., 2103; Thompson 2017; Allen, Grigsby and Peters, 2015). This study has attempted to contribute to the commentary and meanings of the components of school leadership, its effectiveness, the characteristics, behaviors and leadership styles. Emphasis was placed on the correlation and interaction of these elements with each other, in the context of a literature review on the subject of educational leadership. In addition, specific characteristics related to the effective exercise of leadership in the field of educational units were reported, recorded and associated with the various leadership styles and effectiveness.

With regard to the research questions and more specifically to the first question, arises through the quotation of the relevant literature that indeed the characteristics of the leader, affect the result of exercised leadership directly or indirectly because these characteristics' enable, contribute, shape and influence the leadership style and consequently the result itself.

Regarding the second research question, it is understood and perceived through the quotation of the relevant literature that indeed the applied leadership style and behavior have a direct effect, because each of these styles which mentioned briefly, work differently to the recipients, contributes, shapes and influences the performance of members of a team to varying degrees, and ultimately each leadership style as we have seen, gives weight to different goals (team development, vision, achieving result, empowering people, satisfying desires, responding to motivation, implementing legislation, fulfilling regulations, etc.) Consequently, the result itself is different, since the leadership style and the target set from this is different as a target from the beginning. These conclusions are in line with the results of another research showed that there was a significant relationship of leadership styles with school effectiveness. Accordingly, characteristics of leadership styles of school head teachers have correlation 
with the characteristics of school effectiveness (Ijaz Ahmad Tatlah and Muhammad Zafar Iqbal, 2012) and each style has its own merits (Mulford, 2008).

As for the third research question it is understood and documented through the quotation of the relevant literature that the most significant component among characteristics', styles and behaviors of leadership effectiveness cannot be defined objectively and accurately. Regarding the concept of effectiveness of educational leadership, important conclusions have emerged in principle in determining it, and also in how to measure and assess the effectiveness of leadership with specific criteria, parameters.

In summary regarding the effectiveness of the educational leadership, we can say that the criticism and evaluation of a leadership on its effectiveness can be interpreted but not measured objectively on the basis of the characteristics of the leader who exercises it, in other words whether the leader possesses and to what extent some or all of the characteristics mentioned in this study. Also, the effectiveness of the educational leadership can be interpreted but not measured objectively on the basis of the leadership style applied by the leader and more specifically, if the implementation of the leadership style that each time is examined, what finally achieves and to what extent their respective objectives pursued. A combination of leadership styles, characteristics and relative behaviors could bring better outcomes.

This is in line with other research that argues that an integrated leadership model that encompasses behaviors and characteristics from transformational, transactional (Mulford, 2008; Hallinger, 2003), inspirational, and instructional leadership styles can provide positive school based leadership (Bradley Smith, 2016). An integrated leadership style approach has mutual beneficial effects on both teacher job satisfactions and in overall student achievement, while "transformational leadership practices are not sufficient for effectiveness unless they are combined with additional leadership behaviors such as those which are linked to instructional leadership (Menon, 2014). Besides according to other studies there is a need for integrated models of leadership (Leithwood \& Sun, 2012).

Eventually, with a more accountable way, the effectiveness of an educational leadership can be interpreted and judged more objectively on the basis of the results produced as compared to the objectives, criteria and targets which are initially have been set. In such a process of evaluating the degree of effectiveness of the educational leadership, specific characteristics of the leader, the leadership style he implements, as well as his behaviour, should also be investigated in order to emerge from this process, what exactly are the areas where education leadership lacks and which of them should be improved.

\subsection{Policy Recommendations and Research Contribution}

It is of a great importance to understand the way that educational leadership impacts many recipients such as students, faculty personnel and teachers. Understanding the effects of educational leadership through its core components, realizing the way and degree of influence that each exercises in the function of the educational administration and its results, recognising which component is more important, can result in better acknowledge of what an educational leader should do in order to enhance his or her competences, to disclose any weaknesses and work on them for improvement, to change leadership style, or adopt other behavior which is more suitable to given circumstances. Eventually the acknowledgment of leadership components influence in daily operation and the successful combination among them, can help leaders to act in a more efficient manner improving to the best the educational leadership outcomes.

This study might be helpful for teachers and school leaders in better understanding the significance of interaction between leader characteristics, behaviors, styles and their impact to effectiveness accordingly. Leaders will become aware to cope with the challenges of the time in regard to improve results, to uplifting and improving school effectiveness, to be competitive and adoptive to the current changes of the times through this contribution. Personal characteristic are essential, while different leadership styles and behaviors produce different results to educational leadership stake holders. Thus, the art of combining them with successful manner may have greater outcomes. This is in line with other study that concludes stating that leaders need to be able to adapt their style to the situation and context, ensuring the results needed are achieved. Leaders need to have awareness of the areas in which they are strong in as well as those where they need to develop or to work with someone who will complement their style (Joyce Mary Claris and Sheela, 2015).

\subsection{Further Research}

It will be reasonable, and will be contributing to research the formulation and design of a specific questionnaire in which all the educational stake holders such as students, teachers, and administrative staff could assess the relative and comparative importance among them of the leader's characteristics', leadership styles' and behaviors 
regarding leadership effectiveness. An applied accordingly evaluation model to a real sample of these recipients could explain the relative contribution significance of each one separated component to leadership effectiveness outcomes.

\section{References}

Adelman, H., \& Taylor, L. (2006). The school leader's guide to student learning supports: New directions for addressing barriers to learning. Thousand Oaks, CA: Corwin Press.

Ahmet, A. (2015). Investigation of transformational and transactional leadership styles of school principals, and evaluation of them in terms of educational administration. Academic Journas, 10(20), 2758-2767. Educational Research and Reviews. https://doi.org/10.5897/ERR2015.2483

Akinola, O. B. (2013). Principals' Leadership Skills and School Effectiveness: The Case of South Western Nigeria. World Journal of Education, 3(5). https://doi.org/10.5430/wje.v3n5p26

Allen, N., Grigsby, B., \& Peters, M. L. (2015). Does leadership matter? Examining the Relationship Among Transformational Leadership, School Climate, and Student Achievement. NCPEA International Journal of Educational Leadership Preparation,10(2). November 2015 ISSN: 2155-9635 (c) 2015 National Council of Professors of Educational Administration.

Amanchukwu, R. N., Stanley, G. J., \& Ololube, N. P. (2015). A Review of Leadership Theories, Principles and Styles and Their Relevance to Educational Management. Management, 5(1), 6-14. https://doi.org/10.5923/j.mm.20150501.02

Avolio, B. J., Walumbwa, F. O., \& Weber, T. J. (2009). Leadership: Current Theories, Research, and Future $\begin{array}{lllll}\text { Directions. } & \text { Annual }\end{array}$ https://doi.org/10.1146/annurev.psych.60.110707.163621

Avollio, B. J., \& Bass, B. M. (1988). “Transformational Leadership, Charisma, and Beyond.” In Emerging Leadership Vistas, edited by J.G. Hunt, H.P. Dachler, B.R. Baliga, and C.A. Schreisheim, 29-49. Lexington, MA: Lexington.

Ayhan, A., Yilmaz, S., \& Şengül, U. (2013). The Effect of School Principals' Leadership Styles on Teachers' Organizational Commitment and Job Satisfaction. Educational Sciences: Theory \& Practice - 13(2) • Spring - 806-811 ․ Educational Consultancy and Research Center.

Barnett, K., \& McCormick, J. (2004). Leadership and individual principal-teacher relationships in schools. Educational Administration Quarterly, 40(3), 406-434. https://doi.org/10.1177/0013161X03261742

Barnett, K., McCormick, T. \& Conners, R. (2001). Transformational leadership in schools.Journal of Educational Administration, 39(1), 24-46. https://doi.org/10.1108/09578230110366892

Barth, R. S. (2011). "Teacher Leader." In Blair Hilty, E. (ed.) Teacher Leadership. The "New" Foundations of Teacher Education, pp. 22-33. New York: Peter Lang Publishing.

Bass, B. (1998). Transformational leadership: Industry, military, and educational impact. Mahwah, NJ: Erlbaum Associates.

Bass, B. M. (1985). Leadership and performance beyond expectations. Free Press; Collier Macmillan.

Bass, B. M. (1997). Does the transactional-transformational leadership paradigm transcend organizational and national boundaries? American Psychologist, 52(2), 130-139. https://doi.org/10.1037/0003-066X.52.2.130

Bass, B. M.,\& Avolio, B. J. (1994). Improving organizational efectiveness through transformational leadership. Tousand Oaks, CA: Sage.

Bass, B., \& Bass, R. (2008). The Bass Handbook of Leadership: Theory, Research and Managerial Application. New York: Simon \& Schuster.

Bass, B., \& Riggio, R. (2006). Transformational leadership. New York, NY: Taylor and Francis. https://doi.org/10.4324/9781410617095

Beck, L., \& Foster, W. (1999). Administration and community: Considering challenges, exploring possibilities. In J. Murphy \& K. S. Louis (Eds.), Handbook of research on educational administration (337-358). San Francisco: Jossey-Bass.

Bird, J., Wang, C., Watson, J., \& Murray, L. (2009). Relationships among principal authentic leadership and teacher trust and engagement levels. Journal of School Leadership, 19(2), 153-171. https://doi.org/10.1177/105268460901900202 
Blatt, D. A. (2002). A study to determine the relationship between the leadership styles of career technical directors and school climate as perceived by teachers. Dissertation in Education Leadership. West Virginia University.

Bolger, R. (2001). The influence of leadership style on teacher job satisfaction. Educational Administration Quarterly, 37(5), 662-683.https://doi.org/10.1177/00131610121969460

Bradley, S. S. (2016). The Role of Leadership Style in Creating a Great School. SELU-Saskatchewan Educational Leadership Unit Research Review JournalResearch Review Journal, 1(1), 65-78.

Bruggencate, G., Luyten, H., Scheerens, J., \& Sleegers, P. (2012). Modeling the influence of school leaders on student achievement: How can school leaders make a difference? Educational Administration Quarterly, 48(4), 699-732. https://doi.org/10.1177/0013161X11436272

Burns, J. M. (1978). Leadership. New York: Harper \& Row.

Bush, T. (2007). Educational leadership and management: theory, policy, and practice. South African Journal of Education EASA, 27(3), 391-406.

Canute, S. T. (2017). Teachers' Expectations of Educational Leaders' Leadership Approach and Perspectives on the Principalship: Identifying Critical Leadership Paradigms for the 21st Century. Journal of Organizational and Educational Leadership, 2(2), Article 3.

Catano, N., \& Stronge, J. H. (2006). What Are Principals Expected to Do? Congruence Between Principal Evaluation and Performance Standards. NASSP Bulletin, 90(3), 221-237. https://doi.org/10.1177/0192636506292211

Charry, K. (2012). Leadership Theories - 8 Major Leadership Theories. Retrieved from http://psychology.about.com/od/leadership/p/leadtheories.htm

Chin, J. (2007). Meta-analysis of transformational school leadership effects on school outcomes in Taiwan and the USA. Asia Pacific Education Review, 8(2), 166-177. https://doi.org/10.1007/BF03029253

Clifford, M., Menon, R., Gangi, T., Condon, C., \& Hornung, K. (2012). Measuring School Climate for Gauging Principal Performance. A Review of the Validity and Reliability of Publicly Accessible Measures. American Institutes for Research. https://doi.org/10.1037/e572172012-001

Cohen, J., McCabe, E., Michelli, N., \& Pickeral, T. (2009). School climate: Research, policy, practice, and teacher education. Teachers College Record, 111(1), 180-213.

Cotton, K. (2003). Principals and student achievement: What the research says. Alexandria, VA: Association for Supervision and Curriculum Development.

Darling-Hammond, L., \& Richardson, N. (2009). Research review/teacher learning: What matters. Educational Leadership, 66(5), 46-53.

Eval, O., \& Roth, G. (2011). Leadership and teachers' motivation: Self-determination theory analysis. Journal of Educational Administration, 49(3), 256-275. https://doi.org/10.1108/09578231111129055

Everard, K. B., \& Morris, G. (1999). Effective educational administration. Patra: EAP.

Fiedler, F. E. (1976). The leadership game: Matching the man to the situation.Organizational Dynamics, 4(3), 616. https://doi.org/10.1016/0090-2616(76)90032-2

Finnigan, K., \& Stewart, T. (2009). Leading change under pressure: An examination of principal leadership in lowperforming schools. Journal of School Leadership, 19(5), 586-618. https://doi.org/10.1177/105268460901900504

Fullan, M. (2001). Leading in a culture of change. San Francisco, CA: Jossey-Bass.

Geijsel, F., Sleegers, P., Leithwood, K., \& Jantzi, D. (2003). Transformational leadership effect on teachers' commitment and effort toward school reform. Journal of Educational Administration, 41(3), 228-256. https://doi.org/10.1108/09578230310474403

Gosling, B. R., Manterano, J., \& Denisson, P. (2003). A Review of Leadership Theory and Competency Frameworks.

Gregory, R. L. (2001). The Oxford Companion to the Mind. Oxford: Oxford University Press.

Griffith, J. (2004). Relationship of principal transformational leadership to school staff job satisfaction, staff turnover, and school performance. Journal of Educational Administration, 12(3), 336-356. https://doi.org/10.1108/09578230410534667 
Hallinger, P. (2003). Leading educational change: Reflections on the practice of instructional and transformational leadership. Cambridge Journal of Education, 33(3), 329-352. https://doi.org/10.1080/0305764032000122005

Hallinger, P., \& Heck, R. (1996). Reassessing the principal's role in school effectiveness: A review of empirical research, 1980-1995. Educational Administration Quarterly, 32(1), 5-44. https://doi.org/10.1177/0013161X96032001002

Hargreaves, A., \& Fink, D. (2008). Distributed leadership: Democracy or delivery? Journal of Educational Administration, 46(2), 229-240. https://doi.org/10.1108/09578230810863280

Harris, A. (ed.) (2009). Distributed leadership: different perspectives, London: Springer. https://doi.org/10.1007/978-1-4020-9737-9

Harris, A., \& Mujis, D. (2005). Improving schools through teacher leadership. Mainhead: Open University Press.

Hauserman, C. P., \& Stick, S. (2013). Te leadership teachers want from principals: Transformational. Canadian Journal of Education, 36(3), 184-203.

Heck, R. H., \& Hallinger, P. (2009). Assessing the contribution of distributed leadership to school improvement and growth in math achievement. American Educational Research Journal, 46(3), 659-689. https://doi.org/10.3102/0002831209340042

Henderson, A. T., \& Mapp, K. L. (2002). A new wave of evidence: The impact of school, family, and community connections on student achievement. Austin, TX: Southwest Educational Development Laboratory.

Hipp, K. A. (1996). Teacher Efficacy: Influence of Principal Leadership Behavior. Paper presented at the annual meeting of the American Educational Research Association. New York. (ERIC Document Reproduction Service No. ED396409).

Hoy, W. K., \& Miskel, C. G. (2010). Eğitim yönetimi: Teori, araştırma ve uygulama (Çev. Turan S.). Ankara: Nobel Yayınları.

Hoy, W. K., \& Miskel, G. C. (2008). Educational Administration: Theory Research and Practice. (8th edition) New York: Mc Graw-Hill. Irwin.

Ibrahim, A. S., \& Al-Teneiji, S. (2013). Principal leadership style, school performance, and principal effectiveness in Dubai schools. International Journal of Research Studies in Education, 2(1), 41-54. https://doi.org/10.5861/ijrse.2012.86

Ijaz, A. T., \& Muhammad, Z. I. (2012). Leadership Styles and School Effectiveness: Empirical Evidence from Secondary Level. International Conference on Education and Educational Psychology (ICEEPSY 2012). Procedia - Social and Behavioral Sciences, 69, 790-797. https://doi.org/10.1016/j.sbspro.2012.11.474

Joyce, M. C. D’Sa, \& Sheela, G. (2015). School Effectiveness In Relation to Leadership Behaviour. International Journal of Education and Psychological Research (IJEPR), 4(2).

Katz, D., \& Kahn, R. L. (1978). The Social Psychology of Organizations (2nd ed.). New York: Wiley.

Katzenmeyer, M., \& Moller, G. (2001). Awakening the Sleeping Giant. Helping Teachers Develop as Leaders, 2nd edn. Thousand Oaks, CA: Corwin Press.

Kruger, M., Witziers, B., \& Sleegers, P. (2007). The impact of school leader variables on school level factors: Validation of a casual model. School Effectiveness and School Improvement, 18(1), 1-20. https://doi.org/10.1080/09243450600797638

Leithwood, J., \& Jantzi, D. (2000). The effects of transformational leadership on organizational conditions and student engagement. Journal of Educational Administration, 38(2), 112-129. https://doi.org/10.1108/09578230010320064

Leithwood, K. (1994). Leadership for school restructuring. Educational Administration Quarterly, 30(4), 498-518. https://doi.org/10.1177/0013161X94030004006

Leithwood, K. (2002). Organizational learning and school improvement. Greenwich, CT: JAI.

Leithwood, K. A., \& Jantzi, D. (2002). Thoughts behind 'Transfrmational leadership effect on school organization and student engagement with school. In M. Wallace (Ed.), Learning to read critically in educational management. Thousand Oaks, CA: Sage.

Leithwood, K. A., Jantzi, D., \& Steinbach, R. (1999). Changing leadership for changing times. Buckingham, UK: Open University Press. 
Leithwood, K., \& Jantzi, D. (2008). Linking leadership to student learning: The role of collective efficacy. Educational Administration Quarterly, 44(4), 496-528. https://doi.org/10.1177/0013161X08321501

Leithwood, K., \& Riehl, C. (2003). What we know about successful school leadership. Philadelphia, P.A.: Laboratory for students Success, Temple University.

Leithwood, K., \& Sun, J. (2012). The Nature and effects of transformational school leadership: A Meta-Analytic review of unpublished research. Educational Administration Quarterly, 48(3), 387-423. https://doi.org/10.1177/0013161X11436268

Leithwood, K., Alma, H., \& Hopkins, D. (2008). Seven strong claims about successful school leadership. School Leadership and Management, 28(1), 2742. https://doi.org/10.1080/13632430701800060

Leithwood, K., Louis, S., Anderson, S., \& Wahlstrom, K. (2004). How leadership influences student learning: review of research. Minneapolis, MN, Center for Applied Research and Educational Improvement, University of Minnesota.

Lopez, E. S., \& Ensari, N. (2014). The effects of leadership style, organizational outcome, and gender on attributional bias towards leaders. Journal of Leadership Studies, 8(2), 19-35. https://doi.org/10.1002/j1s.21326

Lussier, R. N., \& Achua, C. F. (2010). Leadership: Theory, application, skill development (4th ed.). Egan, MN: Thompson South-Western. https://doi.org/10.1016/j.leaqua.2010.07.002

MacBeath, J. (2011). No lack of principles: leadership development in England and Scotland.School Leadership and Management, 31(2), 105-121. https://doi.org/10.1080/13632434.2010.525029

MacKenzie, S. B., Podsak, M., \&Rich, G. A. (2001). Transformational and transactional leadership and sales person performance. J. Acad. Market. Sci., 29(2), 115-134. https://doi.org/10.1177/03079459994506

Marzano, R. J., Waters, T., \& McNulty, B. A. (2005). School Leadership that Works: From Research to Results. Alexandria, VA: Association for Supervision and Curriculum Development.

Masi, R. J., \& Cooke, R. A. (2000). Effects of transformational leadership on subordinate motivation, empowering norms and organizational productivity. Int J Organ Anal, 8, 16-47. https://doi.org/10.1108/eb028909

McCarty, D., Wallin, P., \& Boggan, M. (2014). Shared Leadership Model for 21st Century Schools:Principal and Counselor Collaborative Leadership. National Forum of Educational Administration and Supervision Journal, $32(4)$.

McGregor, J. (2000). The challenge of collaboration: what encourages joint work between teachers? Paper presented at the BELMAS Research Conference, Robinson College, Cambridge, UK, 29-31.

Menon, M. W. (2014). The relationship between transformational leadership, perceived leader efectiveness, and teachers' job satisfaction. Journal of Educational Administration, 52(4), 509-528. https://doi.org/10.1108/JEA-01-2013-0014

Mulford, B. (2008). The leadership challenge: Improving learning in schools. Australian Education Review: ACER Press.

Mumford, T. V., Campion, M. A., \& Morgeson, F. P. (2007). The Leadership Skills Strataplex: Leadership skill requirements across organisational levels. The Leadership Quarterly, 18(2007), 154-166. https://doi.org/10.1016/j.leaqua.2007.01.005.

Murphy, J., Vriesenga, M., \& Storey, V. (2007). Educational Administration Quarterly, 1979-2003: An analysis of types of work, methods of investigation, and influences. Educational Administration Quarterly, 43(5), 612628.https://doi.org/10.1177/0013161X07307796

Nguni, S., Sleegers, P. J., \& Denessen, E. (2006) Transformational and transactional leadership effects on teachers' job satisfaction, organizational commitment, and organizational citizenship behavior in primary schools: The Tanzanian case. School Effectiveness and School Improvement, 17(2), 145-177. https://doi.org/10.1080/09243450600565746

Nir, A. E., \& Krano, N. (2006). School principal's leadership style and teachers' self-efficacy. Planning and Changing, 37(3\&4), 205-218.

Northouse, P. G. (1997). Leadership: Theory and Practice, Sage Publications, Thousand Oaks, CA.

OECD. (2008). Improving School Leadership. DIRECTORATE FOR EDUCATION Education and Training Policy Division. Retrieved from http://www.oecd.org/edu/schoolleadership-8 
OECD. (2013). Synergies for Better Learning. An International perspective on evaluation and assessment. OECD reviews of evaluation and assessment in education. Retrieved from http://www.oecd.org/edu/school/synergies-for-better-learning.htm\#Tables

Owens, R. (2004). Organizational behavior in education: Adaptive leadership and school reform. New York, NY: Pearson.

Peterson, T. O., \& Van Fleet, D. D. (2004). The ongoing legacy of R.L.Katz: An updated typology of management skills. Management Decision, 42(10), 1297-1308. http://doi.org/10.1108/00251740410568980

Politis, J. (2001). The relationship of various leadership styles to knowledge management. Leadership \& Organization Development Journal, 22(8), 354-364. https://doi.org/10.1108/01437730110410071

Pont, B., Nusche, D., \& Moorman, H. (2008). Improving school leadership: Policy and practice (Vol. 1). Paris: OECD.

Portin, B. S., Knapp, M. S., Dareff, S., Feldman, S., Russell, F. A., Samuelson, C., \& Ling Yeh, T. (2009). Leadership for Learning Improvement in Urban Schools. University of Washington. Retrieved from $\mathrm{http}: /$ www.wallacefoundation.org/knowledge-center/school-leadership/district-policy-andpractice/Documents/Leadership-for-Learning-Improvement-in-Urban-Schools.pdf

Richter, M. M., Lewis, T. J., \& Haggar, J. (2012). The relationship between principal leadership skills and schoolwide positive behaviour support: An exploratory study. Journal of Positive Behavior Interventions, 14(2), 69-77. http://dx.doi.org/10.1177/1098300711399097

Riley, K., \& MacBeath, J. (1998).Effective Leaders and Effective Schools. In MacBeath, J. (ed.) Effective School Leadership: Responding to Change, 140-152. London: Paul Chapman.https://doi.org/10.4135/9781446252086.n9

Robbins, H., \& Finley, M. (2000). Why teams don't work. What Went Wrong and How to Make it Right. Texere.

Robinson, V., Lloyd, C., \& Rowe, K. (2008). The impact of leadership on student outcomes: An analysis of the differential effects of leadership types. Educational Administration Quarterly, 44(5), 635-674. https://doi.org/10.1177/0013161X08321509

Silins, H., Mulford, B., \& Zarins, S. (2002). Organizational learning and school change. Educational Administration Qarterly, 38(5), 613-642. https://doi.org/10.1177/0013161X02239641

Spillane, J. P. (2005). Distributed Leadership. The Educational Forum,69(2),143-150. https://doi.org/10.1080/00131720508984678

Spillane, J. P., Halverson, R., \& Diamond, J. B. (2001). Investigating school leadership practice: A distributed perspective. School of Education and Social Policy. https://doi.org/10.3102/0013189X030003023

Sun,J., \& Leithwood, K. (2012). Transformational school leadership effects on student achievement. Leadership and Policy in Schools 11(4), 418-451.https://doi.org/10.1080/15700763.2012.681001

Tschannen-Moran, M., \& Tschannenen-Moran, B. (2011). Taking a strengths-based focus improves climate. Journal of School Leadership, 21(3), 422-448. https://doi.org/10.1177/105268461102100305

Ulrich, D., Zenger, J., \& Smallwood, N. (1999). Results Based Leadership, Harvard Business School Press, USA.

Valentine, J., \& Prater, M. (2011). Instructional, transformational, and managerial leadership and student achievement: High school principals make a diference. NASSP Bulletin, 95(1), 5-30. https://doi.org/10.1177/0192636511404062

Vos, D., van der Westhuizen, P., Mentz, P., \& Ellis, S. (2012). Educators and the quality of their work environment: An analysis of the organizational climate in primary schools. South African Journal of Education, 32(1), 5668. https://doi.org/10.15700/saje.v32n1a520

VROOM, V. H. (2000). Leadership And The Decision-Making Process. Organizational Dynamics, $28,82$. https://doi.org/10.1016/S0090-2616(00)00003-6

Waheed, Z., Hussin, S., \& Bin Megat Daud, M. A. K. (2018). The best practices for school transformation: A multiple-case study. Journal of Educational Administration, 56(1), 88-103. https://doi.org/10.1108/JEA-112016-0136

Walker, J., \& Slear, S. (2011). The impact of principal leadership behaviors on the efficacy of new and experienced middle school teachers. NASSP Bulletin, 95(1), 46-64. https://doi.org/10.1177/0192636511406530 
Yu, H., Leithwood, K., \& Jantzi, D. (2002). The effect of transformational leadership on teachers' commitment to change in Hong Kong. Journal of Educational Administration, 38(29), 112-129. https://doi.org/10.1108/09578230210433436

Yukl, G. (1989). Managerial leadership: A review of theory and research. J. Manage, 15(2), 251-289. https://doi.org/10.1177/014920638901500207

Yukl, G. (1999). An evaluative essay on current conceptions of effective leadership. European Journal of Work and Organizational Psychology, 8(1), 33-48. https://doi.org/10.1080/135943299398429

Zimmerman, B. J., \& Cleary, T. J. (2006). Adolescents' development of personal agency. The role of selfefficacy beliefs and self-regulatory skills. In F. Pajares \& T. Urdan (Eds.), Self-efficacy beliefs of adolescents (pp. 4569). Greenwich, CT: Information Age.

Dimopoulos G. Andreas Short CV (email:info@andreasdimopoulos.gr)

Andreas Dimopoulos is a PhD candidate at the Department of Economics of the Democritus University of Thrace. $\mathrm{He}$ is author of the book "Labour Market-Conquer the position you deserve" 'Ziti' Publications, while he has announces and publications in several international conferences and international scientific journals. He addressed a thorough research in issue of employment, integration of new entrants to the job market, employee selection practices and human resources management and has implemented a large number of lectures in many educational institutes' on these issues. He worked for many years in large multinationals companies from various senior managerial positions and has also a profound experience in consulting, mentoring and training in businesses, combined with work experience in Greek Ministry of Education and National Center for Public Administration.

\section{Copyrights}

Copyright for this article is retained by the author(s), with first publication rights granted to the journal.

This is an open-access article distributed under the terms and conditions of the Creative Commons Attribution license (http://creativecommons.org/licenses/by/4.0/). 